\title{
A CRIMINALIZAÇÃO DA HOMOFOBIA PELO SUPREMO TRIBUNAL FEDERAL E OS POSSÍVEIS LIMITES NA FORMAÇÃO DOS PRECEDENTES PENAIS
}

\author{
THE CRIMINALIZATION OF HOMOPHOBIA BY THE SUPREME FEDERAL \\ COURT AND THE POSSIBLE LIMITS IN THE FORMATION OF CRIMINAL \\ PRECEDENTS
}

\begin{abstract}
Fábio Roque da Silva Araújo Mestre e Doutor em Direito Público pela Universidade Federal da Bahia - UFBA. Professor do Mestrado em Direito da Universidade Católica do Salvador - UCSAL. Juiz Federal do Tribunal Regional Federal da $1^{\text {a Região. }}$ fabio.araujo@pro.ucsal.br

Raquel El-Bachá Figueiredo Mestranda em Direito pela Universidade Católica do Salvador - UCSal. Especialista em Direito Público pela Universidade Salvador - UNIFACS. Bacharela em Direito pela Universidade Salvador - UNIFACS. Defensora Pública do Estado do Amazonas. raquel.figueiredo@ucsal.edu.br
\end{abstract}

\begin{abstract}
Resumo: O presente trabalho tem o escopo de averiguar se existem limites na formação de precedentes penais, bem como quais seriam esses limites, partindo da análise da decisão referente à criminalização da homofobia pelo Supremo Tribunal Federal. Para tanto, através de uma pesquisa qualitativa, utilizando-se do método dedutivo e da técnica de revisão bibliográfica, faz-se necessário o estudo da necessidade da criminalização da homofobia, da decisão mencionada, bem como a análise do ativismo judicial em que esta importa e dos possíveis limites para a formação de precedentes no âmbito penal. Verifica-se que a determinação de aplicação da Lei ${ }^{0}$ 7.716/89 às condutas homofóbicas pelo Supremo Tribunal Federal extrapola a sua competência e não observa o princípio da legalidade, tampouco a proibição da analogia in malam partem.
\end{abstract}

Palavras-chave: Criminalização da homofobia. Separação de poderes. Princípio da legalidade.

Abstract: This article aims to ascertain whether there are limits to the formation of criminal precedents, as well as what those limits would be, based on the analysis of the decision regarding the criminalization of homophobia by the Supreme Federal Court. To do, through a qualitative research, using the deductive method and the bibliographic review technique, it is necessary to study the need for homophobia criminalization, the decision mentioned, as well as the analysis of judicial activism in which it matters and the possible limits for the formation of precedents in the criminal sphere. It appears that the determination to apply Law n ${ }^{\circ}$. 7.716 / 89 to homophobic behavior by Federal Supreme Court goes beyond its jurisdiction and does not observe the principle of legality, neither does the prohibition of the analogy in malam partem.

Keywords: Criminalization of homophobia. Separation of powers. Principle of legality.

Para citar este artigo (ABNT NBR 6023:2018)

ARAÚJO, Fábio Roque da Silva; FIGUEIREDO, Raquel El-Bacha. A criminalização da homofobia pelo Supremo Tribunal Federal e os possíveis limites na formação dos precedentes penais. Revista Thesis Juris - RTJ, São Paulo, v. 9, n. 1, p. 53-72, jan./jun. 2020. http://doi.org/10.5585/rtj.v9i1.16546. 
ARAÚJO, Fábio Roque da Silva; FIGUEIREDO, Raquel El-Bacha. A criminalização da homofobia pelo Supremo Tribunal Federal e os possíveis limites na formação dos precedentes penais

\section{Introdução}

O Supremo Tribunal Federal (STF), no dia 13 de junho de 2019, julgou, por maioria, procedentes o Mandado de Injunção $n^{\circ} 4733$ (MI $n^{\circ} 4733$ ) e a Ação Direta de Inconstitucionalidade por Omissão ${ }^{\circ} 26\left(\mathrm{ADO}^{\circ}\right.$ 26), cuja pretensão era a criminalização da homofobia, ao reconhecer a mora inconstitucional do Congresso Nacional e aplicar, com efeitos prospectivos, até que o Congresso Nacional venha a legislar a respeito, a Lei $\mathrm{n}^{\mathrm{o}}$ 7.716/89, conhecida como Lei de Racismo, a fim de estender a tipificação prevista para os crimes resultantes de discriminação ou preconceito de raça, cor, etnia, religião ou procedência nacional à discriminação por orientação sexual ou identidade de gênero.

A criminalização da homofobia faz-se extremamente necessária em razão do grande número de ofensas, agressões e discriminações sofridas pela população LGBT brasileira tãosomente em razão da sua orientação sexual e/ou da sua identidade sexual.

Diante dessa necessidade da criminalização da homofobia, diversos projetos de lei, consolidados posteriormente no Projeto de Lei (PL) $n^{\circ}$ 122/2006, tramitaram no Congresso Nacional. A inércia deliberada do Poder Legislativo quanto à votação desse último projeto, todavia, levou ao seu arquivamento no ano de 2015.

Em razão dessa inércia do Poder Legislativo, foram propostos o Mandado de Injunção $n^{\circ} 4733$ (MI n 4733) e a Ação Direta de Inconstitucionalidade por Omissão nº 26 (ADO n² 26).

A criminalização da homofobia pelo Supremo Tribunal Federal através da decisão supramencionada constituiria ativismo judicial decorrente da inércia do Poder Legislativo, que tem sido recorrente em temas que dizem respeito às minorias, e demanda alguns questionamentos quanto aos limites na formação dos precedentes penais pela Suprema Corte.

Dentre esses possíveis limites na formação dos precedentes penais pelo Supremo Tribunal Federal, estão o princípio da separação de poderes, o princípio da legalidade e a proibição da analogia in malam partem, sendo os dois últimos aplicáveis especificamente no âmbito penal.

Diante do exposto, o artigo tem por objetivo principal averiguar se existem limites na formação de precedentes penais, bem como quais seriam esses limites, partindo da análise da decisão referente à criminalização da homofobia pelo Supremo Tribunal Federal.

Para tanto, faz-se necessário o estudo da necessidade da criminalização da homofobia, das decisões proferidas pelo Supremo Tribunal Federal no mandado de injunção e na ação direta de inconstitucionalidade por omissão que visavam à criminalização dessas condutas, bem como a análise do ativismo judicial em que importaria a decisão e dos possíveis limites para a 
formação de precedentes no âmbito penal. Verificar-se-á, ainda, se a separação dos poderes, o princípio da legalidade e a proibição da analogia in malam partem constituiriam óbices à formação de procedentes penais.

A relevância da pesquisa sobre o tema decorre da necessidade de se verificar se existem limitações que devem ser observadas pelo julgador na formação de precedentes judiciais no âmbito penal e de determinar quais seriam essas limitações.

O presente estudo pautou-se em pesquisa qualitativa, utilizando-se do método dedutivo e da técnica da revisão bibliográfica, consistente na análise de leis, jurisprudência, livros e artigos científicos acerca do tema.

O trabalho foi dividido em quatro capítulos. No primeiro capítulo, será feita a análise da necessidade da criminalização da homofobia e da decisão proferida pelo Supremo Tribunal Federal. No segundo capítulo, tratar-se-á do ativismo judicial diante da inércia do Poder Legislativo. O terceiro capítulo versará sobre o princípio da separação dos poderes, a independência judicial, verificando se houve observância a esse princípio na prolação da decisão pelo Supremo Tribunal Federal. No quarto capítulo, serão estudados o princípio da legalidade e a proibição in malam partem no direito penal, bem como se houve violação a esses ditames com a criminalização da homofobia mediante decisão judicial.

\section{A necessidade da criminalização da homofobia e a decisão do Supremo Tribunal Federal}

A análise da necessidade de criminalização da homofobia passa pela compreensão dos conceitos de orientação sexual e de identidade de gênero, que são elementos da sexualidade humana.

A sexualidade compõe a identidade da pessoa humana e representa uma “[...] dimensão fundamental da constituição da subjetividade, alicerce indispensável para a possibilidade do livre desenvolvimento da personalidade" (RIOS, 2001, p. 90-91).

Daniel Borillo (2010, p. 23) esclarece que a orientação sexual é apenas um elemento da sexualidade enquanto complexo de comportamentos referentes à pulsão sexual e à sua concretização. $\mathrm{O}$ autor leciona que a homossexualidade é a atração sexual dirigida para pessoas do mesmo sexo, que a heterossexualidade consiste na atração pelo sexo oposto e que há ainda a bissexualidade, na qual o sexo do parceiro é indiferente.

A identidade de gênero, por sua vez, corresponde a: 
ARAÚJO, Fábio Roque da Silva; FIGUEIREDO, Raquel El-Bacha. A criminalização da homofobia pelo Supremo Tribunal Federal e os possíveis limites na formação dos precedentes penais

[...] experiência interna e individual do gênero de cada pessoa, que pode ou não corresponder ao sexo atribuído no nascimento, incluindo o senso pessoal do corpo (que pode envolver, por livre escolha, modificação da aparência ou função corporal por meios médicos, cirúrgicos ou outros) e outras expressões de gênero, inclusive vestimenta, modo de falar e maneirismos (PRINCÍPIOS DE YOGYAKARTA, p. 10).

$\mathrm{O}$ art. $3^{\circ}$, inciso IV, da Constituição Federal de 1988 proíbe todas as formas de discriminação, dentre elas as decorrentes de orientação sexual e/ou de identidade de gênero, na medida em que estabelece no rol de objetivos fundamentais da República Federativa do Brasil a promoção "[...] do bem de todos, sem preconceitos de origem, raça, sexo, cor, idade e quaisquer outras formas de discriminação".

Neste sentido, ao tratar da proibição de discriminação, Roger Raupp Rios (2010, p. 715) leciona que o conceito de proibição da discriminação sexual abrange diversas situações, como tratamento desfavorável dado ao heterossexual em razão do seu sexo biológico e gênero, ao homossexual em decorrência da sua orientação sexual e ao travesti ou transexual em razão de sua identidade de gênero.

O princípio da não discriminação, consagrado como objetivo fundamental da República Federativa do Brasil, contrapõe-se, todavia, à realidade social, considerando que o preconceito e a discriminação em razão da orientação sexual e/ou identidade de gênero são praticados de forma recorrente, em virtude da ausência de proteção eficiente do Estado no que diz respeito à população LGBT.

Segundo Daniel Borillo (2010, p. 36), a homofobia consiste na:

[...] hostilidade geral, psicológica e social, em relação àqueles de que se supõe que desejam indivíduos de seu próprio sexo ou tenham práticas sexuais com eles. Forma específica de sexismo, a homofobia rejeita a todos os que não se conformam com o papel determinado por seu sexo biológico. Construção ideológica consistente na promoção de uma forma de sexualidade (hétero) em detrimento de outra (homo), a homofobia organiza uma hierarquização das sexualidades e extrai dela consequências políticas.

A população LGBT é frequentemente vítima de ofensas, agressões e discriminações em razão da sua orientação sexual e/ou identidade de gênero no Brasil, como atestam dados decorrentes de relatório elaborado pelo então Ministério dos Direitos Humanos, intitulado "Violência LGBTfóbicas no Brasil: dados da violência". O citado relatório, que se refere a dados colhidos no ano de 2016, confirmando o que já havia sido constatado por meio de relatórios anteriores do mesmo Ministério, aponta para um quadro de violência sistemática no Brasil contra a população LGBT e salienta que foram registradas 2.964 violações de direitos humanos de caráter homofóbico ou transfóbico naquele período (BRASIL, 2018, p. 74). 
Diante dessa necessidade da criminalização da homofobia e da transfobia, foram apresentados os Projetos de Lei (PL) 4.242/03, 3.770/00, 05/2003 e 5.003/2001, reunidos posteriormente no PL 122/2006, que tramitava no Congresso Nacional e que, por ficar sem movimentação durante dois anos no Senado Federal, foi arquivado em 2015, demonstrando a inércia do Poder Legislativo em cumprir a sua função de legislar.

Henrique Alexander Grazzi Keske e Veronica Coutinho Marchini (2019, p. 44) afirmam que o PL 122/2006 foi duramente criticado pelos parlamentares que compõem a denominada bancada evangélica, por acreditarem que o mencionado projeto de lei restringiria a liberdade religiosa e proporcionaria direitos especiais aos homossexuais.

Observe-se que a inércia do Poder Legislativo em cumprir sua função de legislar é recorrente, notadamente no que diz respeito a temas sensíveis e os que se referem à população LGBT. Essa "neutralidade" é proposital e tem por finalidade não provocar desgaste nem perda de capital político perante determinados setores da sociedade.

Neste sentido, Gabriela Soares Balestro e Alexandre Melo Franco de Moraes Bahia (2018, p. 163) apontam que, no âmbito federal, o Poder Legislativo não toma partido na defesa dos direitos da população LGBT, mantendo-se propositalmente inerte, por haver uma grande resistência à aprovação de projetos de lei que disponham acerca da promoção de direitos dessa população em decorrência da oposição dos membros da bancada evangélica. Os autores acrescentam, ainda, que essa omissão do Poder Legislativo demonstra a existência de um pensamento arcaico, conservador, excludente e antidemocrático, que se distancia da realidade do país e do compromisso de representatividade dos parlamentares (2018, p. 170).

Cumpre salientar que art. $5^{\circ}$, em seus incisos XLI e XLII, da Constituição Federal de 1988 prevê mandados de criminalização ao legislador, que não admitem a sua liberdade de conformação. Os referidos incisos dispõem, respectivamente, que "a lei punirá qualquer discriminação atentatória dos direitos e liberdades fundamentais" e "a prática do racismo constitui crime inafiançável e imprescritível, sujeito à pena de reclusão, nos termos da lei” (BRASIL, 1988). Neste sentido, observa-se que o mandado de criminalização referente ao racismo foi cumprido pelo legislador com a edição da Lei $n^{0} 7.716 / 89$, entretanto deixou de ser cumprido quanto às condutas específicas discriminatórias em razão da orientação sexual e/ou da identidade de gênero do indivíduo.

Gabriela Soares Balestro e Alexandre Melo Franco de Moraes Bahia (2018, p. 156) afirmam que essa omissão do Poder Legislativo quanto à criminalização da homofobia consiste em proteção deficiente, tendo em vista que a violência perpetrada contra a população LGBT é 
ARAÚJO, Fábio Roque da Silva; FIGUEIREDO, Raquel El-Bacha. A criminalização da homofobia pelo Supremo Tribunal Federal e os possíveis limites na formação dos precedentes penais

rotineira e os mecanismos atuais do direito brasileiro não tem o condão de contê-la, tampouco de punir os agressores.

Em razão dessa inércia do Poder Legislativo, foram propostos o Mandado de Injunção $n^{\circ} 4733$ (MI n 4733) e a Ação Direta de Inconstitucionalidade por Omissão n ${ }^{\circ} 26$ (ADO n 26), pela Associação Brasileira de Gays, Lésbicas e Transgêneros - ABGLT - e pelo Partido Popular Socialista - PPS -, respectivamente.

As duas ações, subscritas pelo mesmo advogado, requereram que fosse declarada a mora inconstitucional do Congresso Nacional na criminalização específica da homofobia e da transfobia; que fosse fixado prazo razoável para que o Congresso Nacional aprovasse legislação criminalizadora de todas as formas de homofobia e transfobia, e, caso transcorresse o prazo fixado pelo Supremo Tribunal Federal sem que o Congresso Nacional efetivasse a criminalização específica ou caso a Corte entendesse desnecessária a fixação desse prazo, que fossem efetivamente tipificadas a homofobia e a transfobia como crime específico por decisão do próprio Supremo Tribunal Federal. No caso de tipificação das referidas condutas como crime pelo próprio Supremo Tribunal Federal, foi requerido que essa tipificação se desse através da inclusão da criminalização específica da homofobia na Lei ${ }^{\circ}$ 7.716/89, conhecida como Lei de Racismo, determinando a aplicação dessa lei para punir tais atos até que o Congresso Nacional se digne a criminalizar essas condutas ou, subsidiariamente, com a efetivação da criminalização da forma que o Supremo Tribunal Federal julgasse mais pertinente em termos constitucionais. ${ }^{1}$

Os principais fundamentos das ações, em síntese, são a proteção deficiente caracterizada pela inexistência de criminalização específica das ofensas (individuais e coletivas), dos homicídios, das agressões e discriminações motivadas pela identidade sexual e/ou identidade de gênero, real ou suposta, que inviabiliza, inclusive, o direito fundamental à segurança da população LGBT; e a existência de mandado constitucional de criminalização da homofobia e da transfobia, considerando que essas condutas constituem espécie do gênero racismo, além de se enquadrarem no conceito de discriminações atentatórias dos direitos e liberdades fundamentais. $^{2}$

Quanto aos crimes de racismo, observe-se que sua tipificação resulta da Lei $n^{0} 7.716 / 89$, segundo a qual são punidos crimes decorrentes "[...] de discriminação ou preconceito de raça, cor, etnia, religião ou procedência nacional."

\footnotetext{
${ }^{1}$ Os pedidos constam das fls.83-88 da petição inicial do MI n ${ }^{\circ} 4733$ e das fls.93-98 da petição inicial da ADO nº 26, disponíveis na consulta processual do site do Supremo Tribunal Federal.

${ }^{2}$ A síntese dos fundamentos do Mandado de Injunção no 4733 e da Ação Direta de Inconstitucionalidade por Omissão $n^{\circ} 26$ está disposta, respectivamente, às fls.2-4 da petição inicial do MI no 4733 e às fls.2-4 da petição inicial da $\mathrm{ADO}^{\circ}{ }^{\circ} 26$, disponibilizadas na consulta processual do site do Supremo Tribunal Federal.
} 
$\mathrm{O}$ argumento de que as condutas homofóbicas e transfóbicas constituem espécie do gênero racismo, por sua vez, decorre do julgado do Supremo Tribunal Federal no Habeas Corpus $n^{\circ} 82.424 /$ RS que entendeu que manifestações antissemitas constituem crime de racismo. No referido julgamento, a Suprema Corte concebeu um novo conceito do que seria o racismo, destacando seu caráter político-social e não apenas biológico. Assim, o racismo consistiria na supremacia de um grupo sobre outro, não importando a origem, raça ou orientação sexual do indivíduo.

Acolhendo os pleitos do Mandado de Injunção no 4733 (MI n 4733) e da Ação Direta de Inconstitucionalidade por Omissão no 26 (ADO n 26), o Supremo Tribunal Federal, no dia 13 de junho de 2019, julgou, por maioria, procedentes as referidas ações.

No julgamento do Mandado de Injunção no 4733 (MI no 4733), o Supremo Tribunal Federal reconheceu a mora inconstitucional do Poder Legislativo e aplicou, com efeitos prospectivos, até que o Congresso Nacional exerça sua função de legislar sobre o tema, a Lei no 7.716/89, estendendo a tipificação dada ao crime de racismo à homotransfobia (BRASIL, 2019a).

Outrossim, no julgamento da Ação Direta de Inconstitucionalidade por Omissão no 26 (ADO $n^{\circ}$ 26), o Supremo Tribunal Federal reconheceu a mora inconstitucional do Poder Legislativo em cumprir o mandado de criminalização decorrente dos incisos XLI e XLII do art. $5^{\circ}$ da Constituição Federal para proteção penal da população LGBT, declarou a existência da omissão, cientificou o Congresso Nacional da citada mora e deu interpretação conforme a Constituição para enquadrar qualquer forma de manifestação da homofobia e da transfobia nos diversos tipos penais previstos na Lei $\mathrm{n}^{\circ} 7.716 / 89$, até que seja editada legislação sobre o assunto pelo Congresso Nacional, considerando que as práticas homotransfóbicas são espécies do gênero racismo em sua dimensão social (BRASIL, 2019b, p. 156-157).

A mencionada decisão do Supremo Tribunal Federal, em sede de controle abstrato de constitucionalidade, ressalta, ainda, que a interpretação conforme a Constituição dada para enquadrar as condutas homotransfóbicas nos tipos penais previstos na Lei $n^{\circ}$ 7.716/89 não importaria em violação aos princípios da legalidade e da separação dos poderes, tampouco seria analogia in malam partem.

Ocorre que, da análise do próprio voto do relator Ministro Celso de Melo, verifica-se que seu entendimento é de que a colmatação, através de decisão judicial do Supremo Tribunal Federal, da omissão apontada na ação direta, efetuando a tipificação penal das condutas homofóbicas e transfóbicas constitui “[...] clara transgressão ao postulado constitucional da 
ARAÚJO, Fábio Roque da Silva; FIGUEIREDO, Raquel El-Bacha. A criminalização da homofobia pelo Supremo Tribunal Federal e os possíveis limites na formação dos precedentes penais

separação de poderes e, também, ofensa manifesta ao princípio da reserva absoluta de lei formal em matéria de índole penal" (BRASIL, 2019b, p. 26).

A fim de justificar o enquadramento das condutas homotransfóbicas nos diversos tipos penais previstos na Lei $n^{\circ} 7.716 / 89$, o Ministro Celso de Melo, no entanto, afirma que o Supremo Tribunal Federal pode conferir solução que possibilite a aplicação da norma constitucional de eficácia limitada, que seria o mandado de criminalização da homofobia. Essa solução decorreria da interpretação conforme a Constituição dada ao conceito de raça disposto na Lei $\mathrm{n}^{\circ} 7.716 / 89$, sem que isso importasse em analogia in malam partem, acolhendo o argumento da Procuradoria-Geral da República (BRASIL, 2019b, p. 69).

O voto do Ministro Celso de Melo também aponta que não há violação aos princípios da legalidade e da separação de poderes, por considerar que o procedimento hermenêutico não pode afetar a força normativa da Constituição deixando de conferir máxima eficácia aos postulados da dignidade da pessoa humana e da igualdade jurídica, bem como que o processo hermenêutico não se confunde com o processo de elaboração legislativa (BRASIL, 2019b, p. 91-92).

Faz-se necessária, todavia, a verificação da procedência ou não desses argumentos utilizados pelo Supremo Tribunal Federal para justificar a criminalização de condutas através de decisão judicial.

\section{$2 \mathrm{O}$ ativismo judicial diante da inércia do poder legislativo}

A Constituição Federal de 1988 promoveu alterações substanciais no modelo de jurisdição constitucional, fortalecendo o Supremo Tribunal Federal, que começou a ser instado a se manifestar sobre os mais diversos e complexos temas, envolvendo conteúdos políticos, morais, econômicos, religiosos e sociais (LEITE, 2014, p. 11).

Glauco Salomão Leite (2014, p. 11) afirma que há uma maior tendência em se buscar soluções no Poder Judiciário quando o Poder Legislativo se queda inerte em resolver demandas sociais. Ressalte-se que essa omissão do Poder Legislativo pode ter origem na incapacidade de se chegar a um entendimento acerca de um determinado tema ou mesmo num subterfúgio para obstar a tomada de uma decisão sobre uma questão polêmica, em virtude do seu alto custo político (LEITE, 2014, p. 12).

Assuntos como a criminalização da homofobia, discutida no presente artigo, o reconhecimento da união homoafetiva (ADI n. 4277 e ADPF n. 132) e a interrupção da gestação em caso de anencefalia (ADPF n. 54) necessitaram ser decididos pelo Supremo Tribunal 
Federal, a fim de efetivar direitos fundamentais assegurados pela Constituição, em decorrência da inércia deliberada do Poder Legislativo, que se absteve em decidir sobre tais questões diante do seu elevado custo político.

Segundo Andrei Koerner (2016, p. 233), “ativismo judicial é um termo utilizado para apreciar as instituições e agentes judiciais nas democracias contemporâneas, com o qual se coloca o problema do papel apropriado do Poder Judiciário, o modelo de decisão judicial e o comportamento dos juízes".

Neste sentido, a transformação dos padrões tradicionais da atuação judicial afasta o papel do juiz de mero solucionador de demandas e o coloca no patamar de questionador do sistema jurídico ao concretizar valores essenciais à proteção do meio social (HUTZLER, 2018, p. 101).

Essa modificação nos parâmetros clássicos da atuação judicial "[...] implicou na aceitação de novos mecanismos, aptos a satisfazer as prerrogativas judiciais de solucionar o caso concreto com base não apenas na aplicação limitada da norma, mas também com fulcro na atividade de proteção às minorias [...]” (HUTZLER, 2018, p. 102).

O ativismo judicial está intimamente relacionado ao fenômeno da judicialização. Luís Roberto Barroso (2012, p. 3) leciona que a judicialização consiste na decisão por órgãos do Poder Judiciário de questões de grande repercussão política ou social, que deveriam ser decididas pelas instâncias políticas tradicionais (Congresso Nacional e Poder Executivo). Essa judicialização decorre da cessão de poder para juízes e tribunais e implica diferenças na linguagem, no discurso e na forma de participação da sociedade. Segundo o autor, a judicialização de algumas questões decorre de uma tendência mundial e de outras, emana do modelo institucional brasileiro.

O ativismo judicial, por sua vez, é “[...] a escolha de um modo específico e proativo de interpretar a Constituição, expandindo o seu sentido e alcance" (BARROSO, 2012, p. 6). Segundo Luís Roberto Barroso (2012, p. 6), o ativismo judicial ocorre “[...] em situações de retração do Poder Legislativo, de um certo descolamento entre a classe política e a sociedade civil, impedindo que demandas sociais sejam atendidas de maneira efetiva”.

Assim, a noção de ativismo judicial está relacionada à participação mais ampla e efetiva do Poder Judiciário na concretização de valores constitucionais, interferindo, inevitavelmente, no âmbito de atuação do Poder Legislativo e do Poder Executivo.

Luís Roberto Barroso (2012, p. 6) aponta que o ativismo judicial pode se manifestar através das seguintes condutas: 
ARAÚJO, Fábio Roque da Silva; FIGUEIREDO, Raquel El-Bacha. A criminalização da homofobia pelo Supremo Tribunal Federal e os possíveis limites na formação dos precedentes penais

[...] (i) a aplicação direta da Constituição a situações não expressamente contempladas em seu texto e independentemente de manifestação do legislador ordinário; (ii) a declaração de inconstitucionalidade de atos normativos emanados do legislador, com base em critérios menos rígidos que os de patente e ostensiva violação da Constituição; (iii) a imposição de condutas ou de abstenções ao Poder Público, notadamente em matéria de políticas públicas.

A tese favorável ao ativismo judicial e a um maior protagonismo da jurisdição é lastreada na experiência norte-americana e no papel do judicial review. Ocorre que, diante da dificuldade em diferenciá-lo do fenômeno da judicialização da política, parte significativa dos juristas e juízes brasileiros assimilou o ativismo judicial de forma equivocada, como algo benéfico (STRECK, TASSINARI, LIMA, 2013, p. 750).

Nota-se que no julgamento conjunto do Mandado de Injunção no 4733 (MI no 4733) e da Ação Direta de Inconstitucionalidade por Omissão nº 26 (ADO n² 26), a postura ativista do Supremo Tribunal Federal se deu com o reconhecimento do estado de mora inconstitucional do Poder Legislativo da União, a consequente declaração de sua omissão inconstitucional e a aplicação, com efeitos prospectivos, até que o Congresso Nacional venha a legislar a respeito, da Lei $\mathrm{n}^{\circ}$ 7.716/89, a fim de estender a tipificação prevista para os crimes resultantes de discriminação ou preconceito de raça, cor, etnia, religião ou procedência nacional à discriminação por orientação sexual ou identidade de gênero, em razão de interpretação conforme a Constituição dos mandados de criminalização dispostos nos incisos XLI e XLII do art. $5^{\circ}$ da Constituição Federal.

Quanto ao ativismo que caracteriza a criminalização da homofobia pelo Supremo Tribunal Federal, Clèmerson Merlin Cleve, Ingo Wolfgang Sarlet, Jacinto Nelson de Miranda Coutinho, Lenio Luiz Streck e Flávio Pansieri (2014, p. 3-5) teceram diversas críticas, dentre elas: o Poder Judiciário estaria fazendo um juízo político que caberia ao Poder Legislativo; o enquadramento da homofobia ou transfobia como racismo, além de consistir na vedada analogia in malam partem, configuraria um "panhermeneutismo"; a tese da proteção insuficiente não se presta a fundamentar a criminalização judicial de condutas.

Ao tratar dos efeitos da decisão judicial no controle de constitucionalidade por omissão realizado pelo Supremo Tribunal Federal quanto à criminalização da homofobia, Eric Baracho Dore Fernandes (2014, p. 77-78) afirma que a legalidade penal é óbice intransponível para decisões de natureza concretista no âmbito da jurisdição constitucional e que a única forma de tutela constitucionalmente adequada seria a cientificação da mora ao Congresso Nacional, tendo em vista que não cabe ao Poder Judiciário proferir decisões concretistas de modo a suprir lacunas relativas à existência de normas penais incriminadoras. 
Desta forma, verifica-se que, em que pese haver necessidade de criminalização das condutas homotransfóbicas, o ativismo judicial frequentemente visto nas decisões do Supremo Tribunal Federal diante da inércia do Poder Legislativo não se mostra como a via mais adequada para solucionar o problema.

\section{O Princípio da separação dos poderes e a independência judicial}

O princípio da separação dos poderes está disposto no art. $2^{\circ}$ da Constituição Federal de 1988, segundo o qual "são Poderes da União, independentes e harmônicos entre si, o Legislativo, o Executivo e o Judiciário”. O referido princípio possui status de cláusula pétrea, não podendo, portanto, ser objeto de emendas, reformas ou revisões que tenham por finalidade abolí-lo.

Cabe ressaltar que o princípio da separação dos poderes foi consagrado em todas as Constituições brasileiras, como corolário da "[...] existência e sobrevivência de um Estado preocupado com os direitos fundamentais" (CUNHA JÚNIOR, 2018, p. 915).

Dirley da Cunha Júnior (2018, p. 914) enfatiza “[...] que não basta a divisão de funções do Poder, pois essas diferentes funções podem ser exercidas, de forma concentrada, por um único órgão. É necessário algo mais: que essas distintas funções sejam exercidas por órgãos também distintos."

Inocêncio Mártires Coelho (2009, p. 178) afirma que “[...] o princípio da separação dos poderes, nos dias atuais, para ser compreendido de modo constitucionalmente adequado, exige temperamentos e ajustes à luz das diferentes realidades constitucionais [...]”. Essa flexibilização do princípio da separação dos poderes decorre da inevitabilidade da cessão de espaço para a legislação proveniente do Poder Executivo, a exemplo das medidas provisórias, bem como para a legislação judicial, advinda da criação de juízes e tribunais, essencialmente dos tribunais constitucionais, nos quais frequentemente há a edição de normas de caráter geral, como as denominadas sentenças aditivas proferidas por esses tribunais no âmbito do controle de constitucionalidade (BRANCO; COELHO; MENDES, 2009, p. 178).

No tocante à competência para legislar, é importante mencionar que a norma incriminadora de direito penal é necessariamente emanada do Poder Legislativo da União, em razão do princípio da legalidade ou reserva legal que vigora no Direito Penal, que será explicado adiante.

A separação de poderes, ainda, está fundamentada na independência e na harmonia entre os Poderes. Cumpre salientar, entretanto, que, embora não haja qualquer subordinação ou 
ARAÚJO, Fábio Roque da Silva; FIGUEIREDO, Raquel El-Bacha. A criminalização da homofobia pelo Supremo Tribunal Federal e os possíveis limites na formação dos precedentes penais

dependência entre os Poderes quanto ao exercício de suas funções, a Constituição Federal instituiu um sistema de interferências recíprocas, que visa "à busca do equilíbrio necessário à realização do bem da coletividade e indispensável para evitar o arbítrio e o desmando de um em detrimento do outro" (CUNHA JÚNIOR, 2018, p. 915).

Esse sistema de controle mútuo, conhecido como sistema de "freios e contrapesos" ou checks and balances, pode ser exemplificado, no que diz respeito ao Poder Judiciário, pelo controle de constitucionalidade exercido contra leis, atos normativos ou omissões legislativas inconstitucionais.

Vale ressaltar que, no exercício do controle de constitucionalidade dos atos e omissões do Poder Legislativo, o Poder Judiciário deve se ater a determinados limites, como o princípio da legalidade e a proibição da analogia in malam partem, que vigoram no Direito Penal, sob pena de extrapolar da sua competência e, consequentemente, violar o princípio da separação dos poderes.

Neste sentido, ao analisar a criminalização da homofobia, Luciana Costa Fernandes (2019, p. 28) afirma que a autorização para que o Supremo Tribunal Federal incluísse uma elementar criminalizadora em uma lei visivelmente altera o jogo republicano, concedendo competência legislativa a um órgão não eleito ao desconsiderar a existência de regras quanto à separação de poderes e à soberania popular no tocante às demandas por mais punição.

Antonio Baptista Gonçalves (2019, p. 29) pondera que, embora se reconheça que a criminalização da homofobia é benéfica à população LGBT, não compete ao Supremo Tribunal Federal assumir a função de legislador constituinte, tendo em vista que seu papel, precipuamente, é resguardar a correta aplicação da Constituição Federal. Segundo o autor, essa invasão da competência alheia dá azo à interpretação de que poderes políticos poderiam influenciar o Supremo Tribunal Federal, quando, em verdade, isso não pode e nem deve acontecer.

Ao tratar do ativismo em matéria penal, quanto à independência judicial, Jorge André de Carvalho Mendonça (2018, p. 338-339) alega que existem diferenças entre a independência dos juízes nos âmbitos cível e criminal. No âmbito cível, a independência se caracteriza pela imparcialidade do juiz, à luz da autonomia da vontade, da igualdade entre cidadão e estado e da finalidade pública prevista na lei e na Constituição. No âmbito penal, entretanto, a independência estaria vinculada à sujeição somente à lei, garantida pela estrita legalidade ou taxatividade dos tipos penais e, consequentemente pela natureza o mais objetivo possível do juízo, não havendo espaço para discricionariedade nesse aspecto. Logo, na seara criminal, o 
afastamento do princípio da legalidade, da taxatividade dos tipos penais e do caráter objetivo daria margem à discricionariedade dos juízos.

Observa-se, portanto, que o juiz penal está adstrito à legalidade, não podendo inovar criando tipos penais ou ampliando o âmbito de aplicação de norma penal incriminadora para abranger conduta que dela não conste expressamente.

\section{Princípio da legalidade e a proibição da analogia in malam partem no Direito penal}

$\mathrm{O}$ art. 5 , inciso XXXIX, da Constituição Federal de 1988 consagra o princípio da legalidade ao dispor que "não há crime sem lei anterior que o defina, nem pena sem prévia cominação legal". Outrossim, o art. $1^{\circ}$ do Código Penal consagra o mesmo princípio, com redação semelhante.

Segundo Luís Carlos Martins Alves Jr. (2015, p. 179), é praticamente unânime a vigência da estrita legalidade no direito penal e essa " [...] estrita legalidade consiste no mandamento constitucional que exige que certas matérias somente possam ser normatizadas por meio de 'lei' formal, ou seja, por provimento normativo emanado do Poder Legislativo".

O princípio da legalidade é tratado pela doutrina, de modo geral, como apenas uma “[...] exigência de prévia tipificação penal do comportamento proibido. E tanto para a definição do crime quanto da pena. De fato, não se pode admitir qualquer margem de arbitrariedade judiciária na aplicação de sanção a um fato definido como crime” (PACELLI; CALLEGARI, 2018, p. 138).

Neru José Giacomolli e Pablo Rodrigues Alflen da Silva (2010, p. 566) lecionam que o princípio da reserva legal ou da legalidade é mais amplo do que o sentido literal do nullum crimen, sine poena, sine lege, uma vez que o cerne do princípio, ou sua perspectiva material, a partir da localização hermenêutica constitucional, está na garantia de proteção dos cidadãos em face do poder punitivo estatal. Do princípio da legalidade ou da reserva legal decorrem três garantias básicas de direito material, que consistiriam na tipicidade, nas sanções e na execução penal, e uma garantia processual, que é a jurisdição. $O$ autor conclui que o princípio da legalidade fundamenta o limite do poder punitivo, mas não dos direitos e das garantias.

Observa-se, portanto, que a função primordial da “[...] legalidade é a limitação do poder punitivo do Estado e a garantia da liberdade individual, segundo determinações prévias e de todos conhecidas" (PACELLI; CALLEGARI, 2018, p. 138).

Eugenio Raúl Zaffaroni e José Henrique Pierangeli (2019, p. 399) ressaltam que uma das mais importantes aplicações do princípio da legalidade é observada na teoria da tipicidade 
ARAÚJO, Fábio Roque da Silva; FIGUEIREDO, Raquel El-Bacha. A criminalização da homofobia pelo Supremo Tribunal Federal e os possíveis limites na formação dos precedentes penais

e que, em decorrência disso, "em qualquer sistema jurídico civilizado do mundo contemporâneo, os tipos são legais, isto é, somente o legislador pode criar, suprimir e modificar os tipos penais". Os autores, ainda, esclarecem que a ordem jurídica brasileira adota esse sistema de tipos legais.

Eugênio Pacelli e André Callegari (2018, p. 139) aduzem que, em decorrência dessa função de garantia do princípio da legalidade, a interpretação das normas incriminadoras obedece a uma lógica peculiar, que tem início com o juízo de subsunção do fato ao tipo, de modo a se exigir a correspondência absoluta entre o fato praticado e aquele descrito no tipo penal. Os autores acrescentam que somente há garantia da punição se houver reserva de lei.

Vale ressaltar que a proibição da analogia em matéria de incriminação ou proibição da analogia in malam partem é um dos principais desdobramentos do princípio da legalidade.

Através da analogia, uma norma prevista no ordenamento jurídico para regular determinada situação é aplicada para situação diversa, para a qual não há previsão legal expressa, sob o fundamento de que as situações são semelhantes entre si.

Ocorre que, no Direito Penal, “[...] a exigência de legalidade - ou de reserva de lei impede que se faça o aludido método de integração, na medida em que o comportamento não proibido expressamente não pode ser exigido de quem quer que seja" (PACELLI; CALLEGARI, 2018, p. 139).

Neste sentido, Eugenio Raúl Zaffaroni e José Henrique Pierangeli (2019, p. 160) lecionam que, na seara criminal, entende-se por analogia a complementação do texto legal de modo a expandi-lo, ao considerar antijurídico o que a lei justifica, reprovável o que a lei não reprova, punível o que a lei não penaliza, proibir o que a lei não proíbe. Os autores asseveram que esse procedimento de interpretação é vedado de forma absoluta no âmbito do direito penal, tendo em vista que somente a lei em sentido estrito é apta a resolver em que situações o Estado deve exercer o seu poder punitivo, sendo defeso ao juiz colmatar eventuais lacunas legais. Concluem, ainda, que, considerando a descontinuidade do direito penal, a própria segurança jurídica que autoriza o uso da analogia no direito civil a proíbe no âmbito do direito penal.

Há, portanto, a proibição do uso da analogia in malam partem, ou seja, em prejuízo da parte, no Direito Penal, principalmente no tocante às normas incriminadoras. Somente é possível no Direito Penal a analogia in bonam partem, para beneficiar a parte (PACELLI; CALLEGARI, 2018, p. 140).

Eugênio Pacelli e André Callegari (2018, p. 140) lecionam, ainda, que não se pode alargar o âmbito de incidência da norma incriminadora, uma vez que esta tem o condão de proteger bens jurídicos, nos estritos limites da descrição típica. Nessa hipótese, a função do 
princípio da legalidade é delimitar a matéria proibitiva. No caso das normas não incriminadoras, cujas finalidades são regulativas, justificadoras da conduta ou excludentes da culpabilidade ou da punibilidade, todavia, não há óbice à aplicação da analogia, principalmente quando favorável à proteção da liberdade individual.

Ademais, não é possível a interpretação extensiva de um tipo penal para abarcar situações que nela não estejam expressamente previstas.

Cumpre salientar que "[...] as normas incriminadoras propriamente ditas são interpretadas pelo processo de subsunção, de tal modo que a descoberta e a aplicação do tipo penal somente terão lugar quando houver a completa e perfeita correspondência entre o fato realizado e a descrição normativa do tipo" (PACELLI; CALLEGARI, 2018, p. 182).

Neste sentido, Eugênio Pacelli e André Callegari (2018, p. 182) esclarecem que não é permitido ao intérprete da norma “[...] qualquer alargamento ou construção de sentido oposto ou não adequado à tipologia penal. Pode-se dizer, com isso, que a hermenêutica das normas incriminadoras obedece a uma rígida e inflexível legalidade."

Juarez Tavares (2018, p. 60) ressalta que uma conduta que não esteja prevista em norma penal incriminadora não pode ser transformada em criminosa através de decisão judicial, ainda que os efeitos dessa decisão tenham relevância social.

Quanto à interpretação conforme a Constituição, utilizada pelo Supremo Tribunal Federal para enquadrar as condutas homotransfóbicas nos tipos penais previstos na Lei $\mathrm{n}^{\circ}$ 7.716/89, Inocêncio Mártires Coelho (2003, p. 138) afirma que toda conformação que implique em excesso é, em verdade, usurpação de competência do Poder Legislativo, na medida em que transforma o intérprete em legislador. O autor salienta, ainda, que, no âmbito do controle de constitucionalidade, os tribunais nunca devem atuar como legisladores, ainda que por meio interpretativo.

No mesmo sentido, em crítica quanto à decisão do Supremo Tribunal Federal que criminalizou a homofobia, Gustavo Badaró (2019, p. 4) pondera que é inadmissível que o julgador possa reputar como crime condutas não tipificadas anteriormente pelo legislador, sob pena de trocar o princípio da legalidade por um de "jurisdicionalidade". O autor conclui que o Supremo Tribunal Federal realizou um "truque ilusionista", uma vez que, como visto anteriormente, embora tenha defendido a legalidade e a impossibilidade de se criar tipos penais através de decisão judicial, de acordo com o voto do Ministro Celso de Mello, utilizou um tipo penal já existente para reputar como crime algo que nele não está descrito (2019, p. 5).

Analisando a decisão do Supremo Tribunal Federal que criminalizou a homofobia, Élcio Arruda (2019, p. 36-37) esclarece que a flexibilização do princípio da legalidade não combina 
ARAÚJO, Fábio Roque da Silva; FIGUEIREDO, Raquel El-Bacha. A criminalização da homofobia pelo Supremo Tribunal Federal e os possíveis limites na formação dos precedentes penais

com democracia. O autor entende que o título "interpretação conforme a Constituição" dado pelo Supremo Tribunal Federal para enquadrar as condutas homotransfóbicas nos tipos penais previstos na Lei $\mathrm{n}^{\mathbf{0}} 7.716 / 89$ constitui um artifício para legitimar a relativização do princípio da legalidade na seara penal.

Não procede, portanto, o argumento de que a interpretação conforme a Constituição não importaria em violação ao princípio da legalidade, à proibição da analogia in malam partem e ao princípio da separação dos poderes.

Desta forma, ainda que exista uma ordem constitucional que obriga o legislador a criminalizar a homofobia e a transfobia, a interpretação conforme a Constituição dada pelo Supremo Tribunal Federal para enquadrar a homofobia e a transfobia, qualquer que seja a forma de sua manifestação, nos tipos penais definidos na Lei $n^{\circ} 7.716 / 89$, por considerar que as condutas homotransfóbicas qualificam-se como espécie do gênero racismo, viola o princípio da legalidade por alargar o âmbito de aplicação da Lei de Racismo para que esta abranja situações que não estão expressamente previstas no texto legal.

\section{Considerações finais}

O presente trabalho analisou a criminalização da homofobia pelo Supremo Tribunal Federal através do julgamento conjunto do Mandado de Injunção no 4733 (MI nº 4733) e da Ação Direta de Inconstitucionalidade por Omissão no 26 (ADO n 26).

Observa-se que, embora houvesse necessidade de criminalização da homofobia, diante do grande número de agressões e condutas discriminatórias em razão da orientação sexual e/ou identidade de gênero, o Poder Legislativo se manteve inerte durante muito tempo, fazendo com que a matéria fosse levada ao Poder Judiciário, com a finalidade de que este se manifestasse quanto à omissão legislativa.

A decisão do Supremo Tribunal Federal que criminalizou as condutas homotransfóbicas importa em ativismo judicial e, como restou demonstrado, existem limites para a formação de precedentes decorrentes desse ativismo no âmbito penal.

O princípio da separação de poderes, o princípio da legalidade e a proibição da analogia in malam partem no Direito Penal são limites para a formação de precedentes penais, que não podem ser flexibilizados de forma alguma pelo julgador.

No caso em tela, constata-se que o Supremo Tribunal Federal violou o princípio da separação de poderes, extrapolando a sua competência, na medida em que deixou de observar o princípio da legalidade, que vigora no Direito Penal, e só permite que condutas sejam 
criminalizadas através de lei em sentido estrito, proveniente do Poder Legislativo. De igual modo, verifica-se a inobservância da proscrição da analogia in malam partem no Direito Penal, que decorre do princípio da legalidade, considerando que o âmbito de aplicação da Lei de Racismo foi alargado para abranger situações que não estão expressamente previstas no texto legal.

Vale ressaltar que o precedente penal firmado pelo Supremo Tribunal Federal com essa decisão é temerário, na medida em que torna possível a criminalização de condutas sem a observância do princípio da legalidade consagrado pela Constituição Federal e expresso como norma penal.

Conclui-se, portanto, que a procedência da pretensão de criminalização da homofobia pelo Supremo Tribunal Federal, com a determinação de aplicação da Lei no 7.716/89 às condutas homotransfóbicas extrapola a sua competência, desrespeitando a separação de poderes, e não observa o princípio da legalidade, tampouco a proibição da analogia in malam partem.

\section{Referências}

ALVES JR., Luís Carlos Martins. O ativismo judicial da "República togada" e o princípio da legalidade na "democracia parlamentar": uma breve análise crítica acerca de algumas decisões do Supremo Tribunal Federal, sob as luzes da separação dos poderes e da soberania popular. Revista Colombiana de Derecho Internacional, n. 27, jul/dez 2015, p. 167-198. Disponível em: http://dx.doi.org/10.11144/Javeriana.il15-27.oajr. Acesso em: 01 out. 2019.

ARRUDA, Élcio. Crime sem lei?. Revista Síntese de direito penal e processual penal, Porto Alegre, v. 19, n. 119, p. 35-38, dez./jan. 2019. Disponível em: http://200.205.38.50/biblioteca/index.asp?codigo_sophia=155247. Acesso em: 21 abr. 2020.

BADARÓ, Gustavo. Legalidade penal e a homofobia subsumida ao crime de racismo: um truque de ilusionista. Jota, 2019. Disponível em:

https://www.jota.info/paywall?redirect_to=//www.jota.info/opiniaoeanalise/artigos/legalidade-penal-e-a-homofobia-subsumida-ao-crime-de-racismo-umtruquede-ilusionista-24052019. Acesso em: 01 out. 2019.

BALESTRO, Gabriela Soares; BAHIA, Alexandre Melo Franco de Moraes. Minorias sexuais e homofobia no direito brasileiro: breves delineamentos constitucionais. Revista Videre, v. 10, n. 19, jan/jun. 2018, p. 148-176. Disponível em:

https://www.researchgate.net/publication/326023795_Minorias_sexuais_e_homofobia_no_dir eito_brasileiro_breves_delineamentos_constitucionais. Acesso em: 01 out. 2019.

BARROSO, Luís Roberto. Judicialização, ativismo judicial e legitimidade democrática.

(Syn)thesis, v. 5, n. 1, 2012. Disponível em: 
ARAÚJO, Fábio Roque da Silva; FIGUEIREDO, Raquel El-Bacha. A criminalização da homofobia pelo Supremo Tribunal Federal e os possíveis limites na formação dos precedentes penais

https://www.epublicacoes.uerj.br/index.php/synthesis/article/view/7433/5388. Acesso em: 01 out. 2019.

BORILLO, Daniel. Homofobia: história e crítica de um preconceito. Belo Horizonte: Autêntica, 2010.

BRANCO, Paulo Gustavo Gonet, COELHO; Inocêncio Mártires; MENDES, Gilmar Ferreira. Curso de direito constitucional. 4. ed. rev. e atual. São Paulo: Saraiva, 2009.

BRASIL. Constituição da República Federativa do Brasil de 1988. Disponível em: http://www.planalto.gov.br/ccivil_03/constituicao/constituicao.htm. Acesso em: 01 out. 2019.

BRASIL. Lei $\mathbf{n}^{\mathbf{0}}$ 7.716/89. Disponível em:

http://www.planalto.gov.br/ccivil_03/leis/17716.htm. Acesso em: 01 out. 2019.

BRASIL. Código Penal. Disponível em: http://www.planalto.gov.br/ccivil_03/decretolei/del2848compilado.htm. Acesso em: 01 out. 2019.

BRASIL. Ministério da Mulher, da Família e dos Direitos Humanos. Violência LGBTFóbicas no Brasil: dados da violência. Elaboração de Marcos Vinicius Moura Silva. Brasília: Ministério dos Direitos Humanos, 2018. Disponível em:

https://www.mdh.gov.br/biblioteca/consultorias/lgbt/violencia-lgbtfobicas-no-brasil-dadosda-violencia. Acesso em: 01 out. 2019.

BRASIL. Supremo Tribunal Federal. Mandado de Injunção no 4733 (MI no 4733). Impetrante: Associação Brasileira de Gays, Lésbicas e Transgêneros - ABGLT. Impetrado: Congresso Nacional. Interessado: União Relator: Min.Edson Fachin. Data do julgamento: 13.06.2019. Disponível em: http://portal.stf.jus.br/processos/detalhe.asp?incidente $=4239576$. Acesso em: 01 out. 2019.

BRASIL. Supremo Tribunal Federal. Ação Direta de Inconstitucionalidade por Omissão $\mathbf{n}^{\mathbf{0} 26}$ (ADO n⿳ 26). Requerente: Partido Popular Socialista - PPS. Interessados: Congresso Nacional e Presidente do Senado Federal. Relator: Min. Celso de Mello. Data do julgamento: 13.06.2019. Disponível em:

http://www.stf.jus.br/portal/cms/verNoticiaDetalhe.asp?idConteudo=423925. Acesso em: 01 out. 2019.

COELHO, Inocêncio Mártires. Interpretação constitucional. 2. ed. Porto Alegre: Sergio Antonio Fabris Editor, 2003.

CLEVE, Clèmerson Merlin; SARLET, Ingo Wolfgang; COUTINHO, Jacinto Nelson de Miranda; STRECK, Lenio Luiz; PANSIERI, Flávio. Senso Incomum. Perigo da criminalização judicial e quebra do Estado Democrático de Direito. Consultor Jurídico, 2014. Disponível em: https://www.conjur.com.br/2014-ago-21/senso-incomumcriminalizacao-judicial-quebra-estado-democratico-direito. Acesso em: 10 jan. 2020.

CUNHA JÚNIOR, Dirley da. Curso de direito constitucional. 12. ed. rev. ampl. e atual. Salvador: JusPODIVM, 2018. 
ARAÚJO, Fábio Roque da Silva; FIGUEIREDO, Raquel El-Bacha. A criminalização da homofobia pelo Supremo Tribunal Federal e os possíveis limites na formação dos precedentes penais

FERNANDES, Eric Baracho Dore. Omissões inconstitucionais e mandados de criminalização: o Mandado de Injunção $n^{\circ} 4733$ e a criminalização da homofobia.

Observatório da Jurisdição Constitucional, a. 7, v. 2, jul/dez 2014, p. 58-79. Disponível em: https://www.portaldeperiodicos.idp.edu.br/observatorio/article/view/1007. Acesso em: 10 jan. 2020.

FERNANDES, Luciana Costa. Criminalização da LGBTQI+fobia no Brasil pós-democrático: possíveis discussões a partir da crítica criminológica. Boletim IBCCRIM, São Paulo, v. 27, n. 322, p. 27-29, set. 2019. Disponível em:

http://200.205.38.50/biblioteca/index.asp?codigo_sophia=153041. Acesso em: 21 abr. 2020.

GIACOMOLLI, Nereu José; SILVA, Pablo Rodrigo Alflen da. Panorama do princípio da legalidade no direito penal Alemão vigente. Revista Direito GV, v. 6, n. 2, jul/dez 2010, p. 565-582. Acesso em: 01 out. 2019.

GONÇALVES, Antonio Baptista. Criminalização da homofobia. Revista Síntese de direito penal e processual penal, Porto Alegre, v. 19, n. 119, p. 9-34, dez./jan. 2019. Disponível em: http://200.205.38.50/biblioteca/index.asp?codigo_sophia=155245. Acesso em: 21 abr. 2020.

HUTZLER, Fernanda Souza. Ativismo judicial no direito comparado. Série Monografias do CEJ, v. 33, 2018, p. 99-113. Disponível em: http://www.jf.jus.br/ojs2/index.php/mono/article/view/2462. Acesso em: 01 out. 2019.

KESKLE, Henrique Alexander Grazzi; MARCHINI, Veronica Coutinho. A criminalização da homofobia no Brasil: análise jurisprudencial e doutrinária. Revista Prâksis, a. 16, n. 2, mai/ago 2019, p. 34-56. Disponível em:

https://periodicos.feevale.br/seer/index.php/revistapraksis/article/view/1761. Acesso em: 01 out. 2019.

KOERNER, Andrei. O ativismo judicial como problema intelectual e político nos Estados Unidos: uma análise crítica. Lua Nova, n. 99, 2016, p. 233-255. Disponível em: http://dx.doi.org/10.1590/0102-6445233-255/99. Acesso em: 01 out. 2019.

LEITE, Glauco Salomão. Inércia legislativa e Ativismo Judicial: A Dinâmica da Separação dos Poderes na Ordem Constitucional Brasileira. Direito, Estado e Sociedade, n. 45, jul/dez 2014, p. 10-31. Disponível em:

https://www.researchgate.net/publication/277620131_Inercia_Legislativa_e_Ativismo_Judici al_A_Dinamica_da_Separacao_dos_Poderes_na_Ordem_Constitucional_Brasileira. Acesso em: 01 out. 2019.

MENDONÇA, Jorge André de Carvalho. O ativismo judicial em matéria penal e sua relação com o sistema brasileiro de precedentes obrigatórios. Revista da AJURIS, v. 45, n. 144, jun 2018, p. 331-348. Disponível em:

http://www.mpsp.mp.br/portal/page/portal/documentacao_e_divulgacao/doc_biblioteca/bibli_ servicos_produtos/bibli_boletim/bibli_bol_2006/Rev-AJURIS_n.144.11.pdf. Acesso em: 01 out. 2019.

PACELLI, Eugênio; CALLEGARI, André. Manual de direito penal: parte geral. 4. ed. rev., atual. e ampl. - São Paulo: Atlas, 2018. 
ARAÚJO, Fábio Roque da Silva; FIGUEIREDO, Raquel El-Bacha. A criminalização da homofobia pelo Supremo Tribunal Federal e os possíveis limites na formação dos precedentes penais

PRINCÍPIOS DE YOGYAKARTA: princípios sobre a aplicação da legislação internacional de direitos humanos em relação à orientação sexual e identidade de gênero. Disponível em: http://www.clam.org.br/uploads/conteudo/principios_de_yogyakarta.pdf. Acesso em: 01 out. 2019.

RIOS, Roger Raupp. A homossexualidade no Direito. Porto Alegre: Editora Livraria do Advogado, 2001.

RIOS, Roger Raupp. Direito da Antidiscriminação, Sexo, Sexualidade e Gênero: a Compreensão da Proibição Constitucional de Discriminação por Motivo de Sexo. In: SARMENTO, Daniel; IKAWA, Daniela; PIOVESAN, Flávia. (Org.) Igualdade, Diferença e Direitos Humanos. 2. tiragem. Rio de Janeiro: Editora Lumen Juris, 2010, p. 695-717.

STRECK, Lenio Luiz; TASSINARI, Clarissa; LIMA, Danilo Pereira. A relação direito e política: uma análise do Judiciário na história brasileira. Pensar, v. 18, n. 3, set/dez 2013, p. 737-758. Disponível em: https://periodicos.unifor.br/rpen/article/view/2808. Acesso em: 21 abr. 2020 .

TAVARES, Juarez. Fundamentos da teoria do delito. Florianopólis: Tirant lo Blanch, 2018.

ZAFFARONI, Eugenio Raúl; PIARANGELI, José Henrique. Manual de direito penal brasileiro: parte geral. 13. ed. rev. e atual. São Paulo: Thomson Reuters Brasil, 2019. 